Proceedings of the 2018 International Scientific Conference 'Economic Sciences for Agribusiness and Rural Economy' No 2, Warsaw, 7-8 June 2018, pp. 203-208

\title{
REASONS FOR INTERNATIONALIZATION OF POLISH FOOD INDUSTRY COMPANIES
}

\author{
Joanna Baran, $\mathrm{PhD}^{1}$ \\ Faculty of Economics Sciences, Warsaw University of Life Sciences - SGGW
}

\begin{abstract}
The primary aim of this article is to identify the reasons for internationalization of Polish food industry companies. As a part of empirical studies, we carried out interviews with managers at 52 of food industry companies. Poland's accession to the EU, the managers' experience gained on foreign markets and geographical proximity of foreign markets were the main determinants of internationalization for the respondents. For food industry companies, EU markets are the most attractive while export activities constitute the most common form of internationalization.
\end{abstract}

Keywords: internationalization, food industry, companies

JEL code: F20

\section{INTRODUCTION}

Nowadays, internationalization of companies is a very intense process. Nonetheless, it should be emphasized that different industries have different reasons that encourage internationalization in companies, different methods of participating in foreign markets as well as different scopes of relationships with foreign partners (Witek-Hajduk, 2010). Poland's accession to the EU has resulted in many opportunities and risks for Polish food industry companies with respect to internationalization. Opportunities include: facilitated access to the EU market for Polish entrepreneurs, increased attractiveness of Polish companies for foreign investors and partners and better opportunities of obtaining financial resources by Polish companies (Baran, 2016). On the other hand, the primary risks include easier access to the Polish market for a larger number of offerors, increased intensity of competition and introduction of new legal regulations (Baran, 2015).
Faced with these changes, Polish food industry companies had to increase their competitiveness. One of the methods of improving competitiveness was to increase the geographical reach of their business, which involved expanding to foreign markets.

The main objective of this article is to identify the reasons for internationalization of Polish food industry companies. Furthermore, the article indicates which markets are perceived by entrepreneurs as the most attractive and which factors on these markets have the largest impact on the adjustment of strategies to conditions at host markets.

\section{THEORETICAL BACKGROUND}

Internationalization is a complex phenomenon that can be analysed from various perspectives and with respect to different dimensions (economic, scientific, political and legal, sociocultural) (Müller, 2004). Internationalization can be analysed across three

\footnotetext{
${ }^{1}$ Corresponding author: Nowoursynowska 166,02-787 Warsaw, Poland, joanna_baran@sggw.pl, +4822 5934060
} 
scales: macro (internationalization of economies), mezzo (internationalization of markets/industries) and micro (internationalization of companies) (Ladi, 2006). Oczkowska emphasizes that internationalization of companies is a function of reasons and tendencies of companies to expand internationally, and to invest in their development outside the borders of their home country as well as to establish foreign partnerships as a part of other forms (Oczkowska, 2007). On the other hand, Rymarczyk presents a simple definition of company internationalization, namely that it is 'any type of business operated by a company abroad' (Rymarczyk, 2004). Upon analysing the definitions of internationalization, we can conclude that internationalization is commonly seen as:

- a stage-based process of a company's development on foreign markets (Johanson and Vahlne, 1990),

- a process of developing business networks on international markets (Johanson and Mattsson, 1988),

- international exposure of a company's resources (Andersen, 1997),

- geographical expansion of business reach to foreign markets (Hollensen, 2004),

- specific forms of internationalization (Rymarczyk, 2004),

- a process of formulating and implementing strategies (Hill, 2013).

It can be noticed that Polish researchers present a rather broad approach to defining internationalization. Most authors assume that we can speak of a company's internationalization beginning with its commencement of business on a foreign market.

The literature also presents various forms of entry to foreign markets; for example, according to Gorynia, these forms include exporting and importing goods, cooperative relationships with foreign partners (including non-capital forms: licence, franchise, management and investment contracts, capital forms and international strategic alliances), or independent operation of business abroad in the form of a local office or branch (Gorynia, 2007).

Moreover, the literature distinguishes between active and passive internationalization, as well as internal and external internationalization. Active interna- tionalization concerns various types of a company's international expansion; on the other hand, passive internationalization is defined as establishing different economic relationships with foreign partners but without operating a business outside the home country. This type of internationalization can include importing goods, purchasing licences from a foreign partner, etc. (Gołębiowski and Witek-Hajduk, 2000; Gorynia 2000). Internal internationalization is based on the development of import activities, while external internationalization is related to a company's expansion to foreign market using export activities (Luostarinen and Hellman, 1993; Welch and Luostarinen, 1993).

Reasons for internationalization of companies can be determined using the theory of transaction cost, the eclectic theory of international production of Dunning, multi-stage theories of internationalization (in particular, the Uppsala model of Johanson, Wiedersheim-Paul and Vahlne) and network-based theories of internationalization developed by Johanson and Mattsson (Johanson and Wiedersheim-Paul, 1975; Dunning, 1988; Johanson and Mattsson, 1988; Johanson and Vahlne, 1990). The aforementioned theories cover issues related to, e.g. the process of internationalization, selection of forms of internationalization, reasons for conducting export activities and direct foreign investments, and selecting a business location abroad.

\section{MATERIAL AND METHODS}

To collect data, we used the method of interviewing managers of food industry companies. Interviewees were chosen randomly. The sampling frame was the database of the national business register (REGON) kept by Statistics Poland (GUS). The database included food industry companies meeting the following criteria:

- 50 or more employees,

- not branches of foreign companies,

- the process of internationalization has occurred at the company.

The first criterion resulted from the fact that large and medium enterprises have dominant share in international trade and direct international investments. 
The second and third criteria were due to the purpose of this research, i.e. the desire to identify the reasons of internationalization of companies that took such action autonomously. Interviews with 52 respondents were carried out in March 2018. The descriptive, tabular and graphical methods were used to present the results of the research.

\section{RESULTS}

The first stage of research consisted in identifying the forms of internationalization used by the companies under consideration. Almost all studied companies indicated export activities as their main form of internationalization (51 answers) - Table 1. Moreover, about $50 \%$ of studied companies declared engaging in import activities. Joint production ventures were operated by $13 \%$ of studied companies. As a part of other forms of internationalization, the respondents also indicated licence agreements with foreign partners as licensors or licensees ( $8 \%$ each) and joint trading ventures and trade branches (10 and $8 \%$ respectively).

In the next stage of the research, the respondents were asked to indicate the main reasons of expanding to foreign markets (Fig. 1). The main reasons for internationalization of food industry companies included
Poland's accession to the EU (4.24) and managerial experience on foreign markets (4.18). The respondents also stated that they considered the geographical proximity of a foreign market (4.02), the availability of cheaper raw materials (4.0) and factors of production (3.9). The respondents' least important grounds for internationalization were marketization of host country economies (3.51) and internationalization of the company's trade agents (3.47). However, attention should be paid to the fact that the companies indicated that the growing homogeneity of needs and requirements of buyers on foreign markets was deemed a less significant factor (3.51).

Enterprises which decided to expand to a given foreign market must view this market, on the one hand, as attractive and, on the other hand, as a market with low business risk. According to this research, EU markets are the most attractive to food industry companies (Table 2). The attractiveness rating of other markets was similar and below average.

We can assume that companies are more predisposed to adapt their strategies to conditions on markets rated by them as the most attractive. Therefore, during the final stage of the research, we asked the respondents to indicate factors that had the largest impact on their change of strategy and the need to adjust to local conditions when expanding to EU

Table 1. Forms of internationalization used by the food companies in examined units $(n=52)$

\begin{tabular}{|l|c|c|}
\hline Forms of internationalization & $\begin{array}{c}\text { Number } \\
\text { of answers }\end{array}$ & $\%$ \\
\hline Export activities & 51 & 98 \\
\hline Import activities & 28 & 54 \\
\hline Licence agreements with a foreign partner-licensor & 4 & 8 \\
\hline Licence agreements with a foreign partner-licensee & 4 & 8 \\
\hline Franchise agreements with a foreign partner-franchisor & 0 & 0 \\
\hline Franchise agreements with a foreign partner-franchisee & 0 & 0 \\
\hline Joint production ventures & 7 & 13 \\
\hline Joint trading ventures & 5 & 10 \\
\hline Trade branch & 4 & 8 \\
\hline Production branch & 1 & 2 \\
\hline
\end{tabular}

Source: own calculations based on interview questionnaire. 
Proceedings of the 2018 International Scientific Conference 'Economic Sciences for Agribusiness and Rural Economy' No 2, Warsaw, 7-8 June 2018, pp. 203-208

ternationalization of the company's trade agents

marketization of economies of host countries

standardization of needs of buyers on foreign markets and the opportunity to standardize marketing activities

cultural proximity of the foreign market

economies of scale

diversification of risk

no possibility of expansion on the domestic market and the opportunity to increase sales abroad

beneficial policies, e.g. trade policy, of host countries

experience gained on a foreign market as the basis for conducting business on subsequent foreign markets availability of cheaper factors of production availability of cheaper raw materials and parts geographical proximity of the foreign market attitude of managers and their experience on foreign markets Poland's accession to the EU

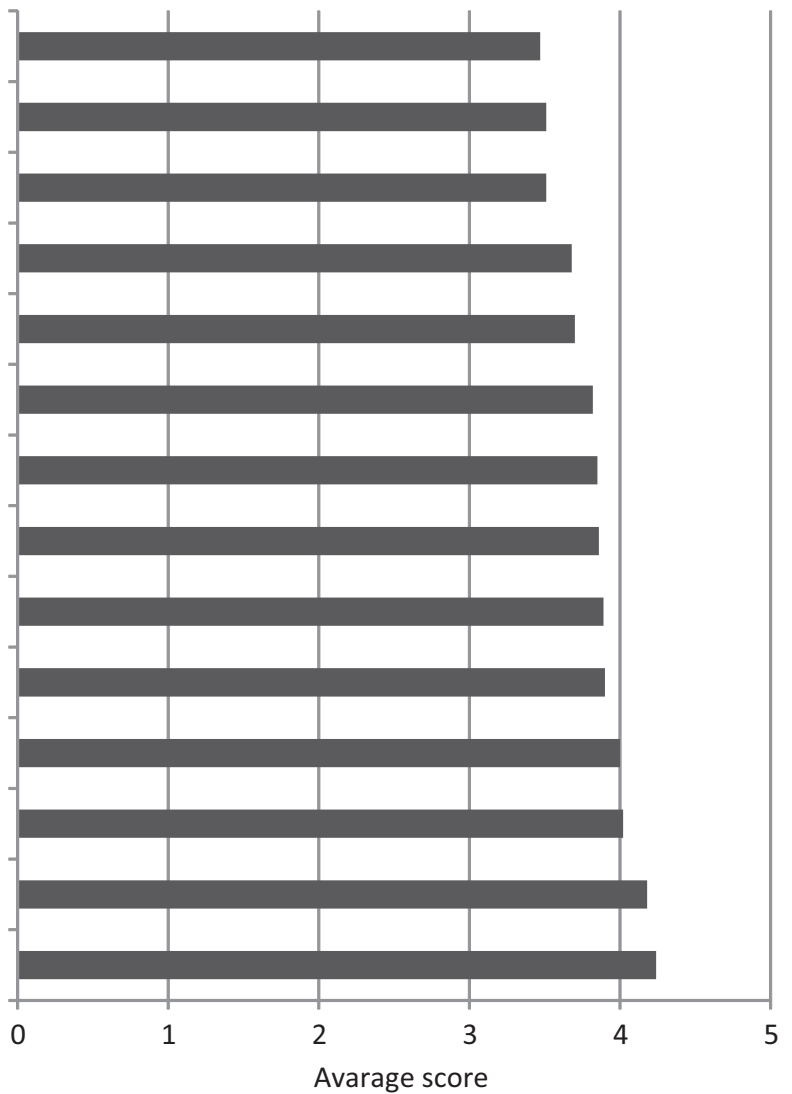

Score ranging from 1 to 5 , where: 5 - definitely important, 4 - important, 3 - neither important nor unimportant, 2 -unimportant, 1 - definitely unimportant.

Figure 1. Reasons for internationalization in the respondents' opinion $(n=52)$

Source: own calculations based on interview questionnaire.

Table 2. Market attractiveness and risk rating in the respondents' opinion $(n=52)$

\begin{tabular}{|l|c|c|}
\hline Markets & Market attractiveness rating & Market risk rating \\
\hline Poland & 2.56 & 2.14 \\
\hline EU countries & 2.44 & 2.07 \\
\hline Russia & 1.65 & 1.61 \\
\hline Asian countries & 1.62 & 1.92 \\
\hline Other countries & 1.61 & 1.61 \\
\hline
\end{tabular}

3 - high market attractiveness, 2 - average attractiveness, 3 - low attractiveness; 3 - low market risk, 2 - average risk, 3 - low risk. Source: own calculations based on interview questionnaire.

markets. Consumer purchasing power and their preferences had the largest influence on the studied companies' adaptation of strategies to conditions of an EU market (Fig. 2). Production standards and brand reputation were also deemed factors that significantly stimulate the adaptation of strategies to conditions in EU countries. Availability of utilities was deemed a less important factor (Fig. 2). 


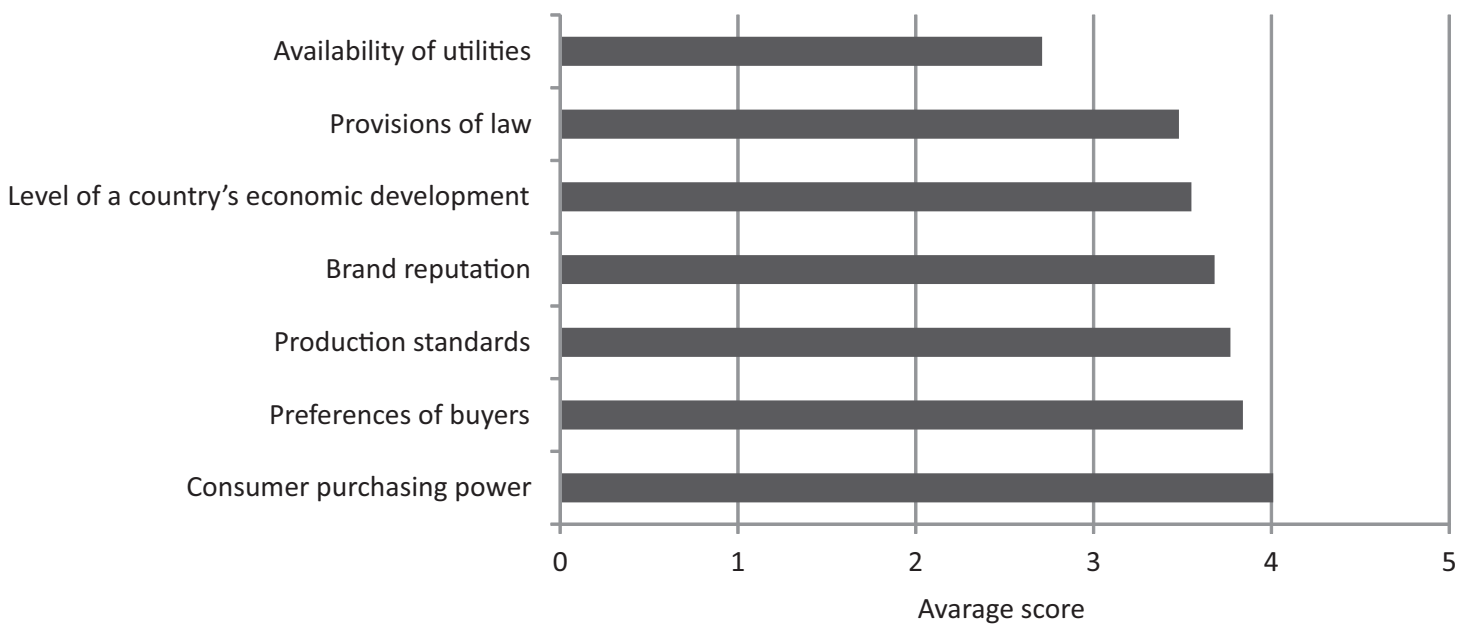

Score ranging from 1 to 5, where: 5 - definitely important, 4 - important, 3 - neither important nor unimportant, 2 - unimportant, 1 - definitely unimportant.

Figure 2. Factors determining the adjustment of strategy to conditions on EU markets

Source: own calculations based on interview questionnaire.

\section{CONCLUSIONS}

Internationalization of companies is a multifaceted and complex phenomenon. Depending on the industry where a given company operates, reasons and models of internationalization vary. The research conducted at Polish food industry companies allowed us to reach the following conclusions:

- the main factors determining internationalization in this sector were Poland's accession to the EU, the managers' experience gained on foreign markets and geographical proximity of foreign markets;

- the most attractive market for studied companies was the Polish market and, among foreign countries, EU markets;

- factors that encourage the adaptation of strategy to conditions on EU markets the most are the purchasing power and preferences of consumers, as well as production standards;

- business risk on the Polish and EU markets is perceived as average, while on the Russian and Asian markets it is seen as above average.

It can be stated that the process of internationalization at Polish food industry companies is conducted in stages and is related to gradual changes in their presence on foreign markets, i.e. according to multi-stage theories of internationalization. It can be assumed that this process will continue to develop rapidly in the sector under consideration, which is why this research should continue, searching for, among other things, factors determining the adoption of a given model of internationalization by companies and relationships between the levels of active and passive internationalization of companies.

\section{REFERENCES}

1. Andersen, O. (1994). Internationalization and market entry mode: a review of theories and conceptual frameworks. Management International Review, 37, pp. 27-42.

2. Baran, J. (2015). Regional differentiation of financial support from the European Union and its impact on agricultural efficiency in Poland. Economic Science for Rural Development: Integrated and Sustainable Regional Development, 38, pp. 227-238.

3. Baran, J. (2016). Globalization processes in Polish food industry. Economic Science for Rural Development: Integrated and Sustainable Regional Development, Production and Co-operation in Agriculture, 42, pp. 200-206.

4. Dunning, J. (1988). The electic paradigm of international production: A restatement and possible extensions. Journal of International Business Studies, 19 (1). https://doi.org/10.1057/palgrave.jibs.8490372 
5. Gorynia, M. (2007). Strategie zagranicznej ekspansji przedsiębiorstw [Strategies of foreign expansion of enterprises]. PWE, Warszawa.

6. Gorynia, M. (2000). Podstawy strategii przedsiebiorstw $\mathrm{w}$ biznesie miedzynarodowym [Basics of corporate strategies in international business]. In: Gorynia, M. (ed.) Strategie przedsiebiorstw w biznesie miedzynarodowym [Business strategies in international business]. Wydawnictwo AE w Poznaniu, Poznań, p. 16.

7. Gołębiowski, T., Witek-Hajduk, M.K. (2007). Formy internacjonalizacji polskich przedsiebiorstw [Forms of internationalization of Polish enterprises]. Marketing i Rynek, 2, pp. 16-17.

8. Hollensen, S. (2004). Global marketing. A decisionoriented approach. Pearson, London.

9. Johanson, J., Mattsson, L.G. (1988). Internationalization of Industrial Systems - A Network Approach. In: Hood, N., Vahlne, J.E. (eds.) Strategies in global competition. Croom Helm, Bezkenham, pp. 198-211.

10. Johanson, J., Vahlne, J-E. (1990). The Mechanism of Internationalization, International Marketing Review, 7 (4). https://doi.org/10.1108/02651339010137414

11. Johanson, J., Wiedersheim-Paul, F. (1975). The internationalization of the firm: Four Swedish cases. Journal of Management Studies, 12 (3), pp. 305-323.

12. Ladi, S. (2006). Globalisation, Policy Transfer and Policy Research Institutes. Edward Elgar Publishing, Cheltenham-Northampton.
13. Luostarinen, R.K., Hellman, H. (1993). Internationalization process and strategies of Finnish family enterprises. In: Procedings of the Conference on the Development. Studies and Reports, 59. Ministry of Trade and Industry.

14. Müller, A. (2004). Globalizacja - mit czy rzeczywistość [Globalization - myth or reality]. In: Czarny, E. (ed.) Globalizacja od A do Z [Globalization from A to Z]. NBP, Warszawa, p. 37.

15. Oczkowska, R. (2007). Przedsiębiorstwo na rynku międzynarodowym. Uwarunkowania strategii internacjonalizacji i globalizacji [An enterprise on the international market. Determinants of internationalization and globalization strategies]. Oficyna Wydawnicza AFM, Kraków.

16. Rymarczyk, J. (2004). Internacjonalizacja i globalizacja przedsiebiorstwa [Internationalization and globalization of the enterprise]. PWE, Warszawa.

17. Witek-Hajduk, M.K. (2010). Strategie internacjonalizacji polskich przedsiębiorstwa w warunkach akcesji Polski do Unii Europejskiej [Strategies for the internationalization of Polish enterprises as part of Poland's accession to the European Union]. Oficyna Wydawnicza SGH, Warszawa.

18. Welch, I.S., Luostarinen, R.K. (1993). Inward - outward connections in internationalization, Journal of International Marketing, 1 (1), pp. 44-56. 